FACTA UNIVERSITATIS

Series: Economics and Organization Vol. 14, $\mathrm{N}^{\mathrm{o}}$ 1, 2017, pp. 1 - 15

DOI: 10.22190/FUEO1701001P

Preliminary communication

\title{
CAN BANKING UNION HELP THE VIABILITY OF EUROZONE BANKING SECTOR? SOME PRELIMINARY RESULTS
}

\author{
UDC 347.734:338.124.4 \\ $339.738(4-672 E U)$
}

\section{Svetlana Popović, Irena Janković}

Faculty of Economics, University of Belgrade, Serbia

\begin{abstract}
Although financial integration and convergence of EMU member countries reached a high level, the financial crisis that has developed into a banking and debt crisis has caused an intense process of fragmentation of financial markets along national borders. This significantly complicated the implementation of the single monetary policy and disrupted the monetary transmission mechanism. Furthermore, in EMU, the crisis was much more intense than in other economies, and was rapidly transmitted among Member States. Besides, the contagion spread quickly from banks to sovereigns and vice versa, creating a "vicious loop" between banks and governmental finances.

This paper attempts to show that adequate, strong and politically independent supranational bank regulation and resolution is necessary for the viability of banking sector, but also the economies in European monetary union. It should restore the market confidence and harmonize the rules of the game in the single financial market. Although the project is on its very beginning, there are some first encouraging results.
\end{abstract}

Key words: banking crisis, sovereign debt crisis, banking union, financial divergence

JEL Classification: E42, E52, F42

\section{THE NEED FOR THE BANKING UNION IN EUROPEAN MONETARY UNION}

The specific regularities that precede or go in parallel with crisis throughout the history include the following: increase in private debt (domestic and external) before the crisis, banking and sovereign crises often joint occurrence and increase in public borrowing (Reinhart \& Rogoff, 2010, p.1-2).

Received November 7, 2016 / Revised January 16, 2017 / Accepted February 2, 2017 Corresponding author: Svetlana Popović

Faculty of Economics, University of Belgrade, Kamenička 6, 11000 Belgrade, Serbia E-mail: ceca@ekof.bg.ac.rs 
Domestic credit rises sharply before the crisis. Household and consumption related debts in Eurozone countries accumulated significantly before the crisis 2007-2008 due to low interest rates and the absence of the foreign exchange risk. During the expansion, the financial sector became richer and more influential. The overconfidence led to underestimation of future shocks that resulted in insufficient asset holdings or too much debt accumulation. Decreased regulation and moral hazard behavior increased financial sector's profitability at the expense of the society. (Reinhart \& Rogoff, 2008).

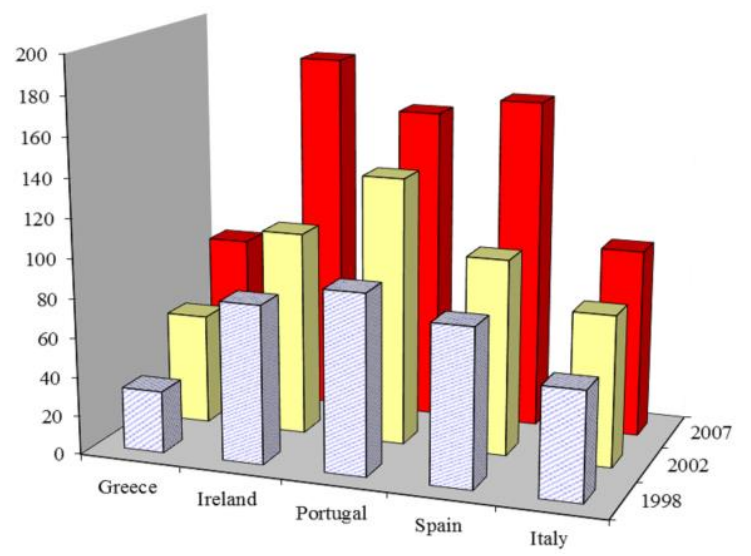

Graph 1 Loans to private sector as \% of GDP for Euro zone periphery Source: Authors' presentation based on World Bank's data

Private debt based on domestic banking credit or foreign borrowing significantly increases before the banking crisis. With the increase of countries' external debt (both private and public) the probability of sovereign and banking crises rises. What Reinhart and Rogoff (2010, p.20) presented for the sample of advanced economies is that average external debt/GDP ratio doubled in the period 1999-2009 leading to global financial crises starting with subprime crises in US in 2007. The similar debt accumulation happened in emerging markets in earlier 1981-1998 period and again from 2008 led by Euro zone periphery countries. Regarding the maturity structure, especially short-term debts escalate before the crisis. As has been confirmed in practice several times - any short term borrowing to finance illiquid assets makes the debtor susceptible to crisis of confidence (Diamond \& Dybvig, 1983). Foreign capital inflows to emerging countries usually increase in the pre-crises years and then suddenly stop just before or during the crisis when foreign investors withdraw from those markets.

The long history of crises shows that banking crises often occur before the sovereign debt crises, although the opposite influence is seen in recent history, too. The banking crisis in large financial centers causes banking crises in other countries and domestic banking crises then leads to sovereign debt crises. The reverse relationship, where public debt accumulation leads to domestic banking crises, is more often seen after 1950s. Private debt surges explain this shift in influence. Increase in the public debt affects the default probability of the sovereign. Concerning the external debt accumulation (both private and public), it increases the chance of the banking crises (Reinhart \& Rogoff, 2010). 
One of the reasons for the increase of the public debt prior and during the sovereign debt crises may lie in the hidden debts and liabilities in implicit government guaranties to government agencies or private domestic borrowers. ${ }^{2}$ The second reason may be the massive debt taking by sovereign from the private banks affected by the crisis. Even without bailouts, since state revenues decrease, sovereign debt rises leading to rating downgrade and defaults. Debts continue to increase even after the default as obligations continues to accumulate and at the same time the GDP contracts (Reinhart et al., 2003). Unfortunately, soon after the debt is restructured countries again start to re-leverage. In addition, when countries have significant amounts of debt denominated in foreign currency, banking crisis precedes the domestic currency crash. The decreasing value of domestic currency leads to insolvency of both private and sovereign debtors that have foreign currency debt on their balance sheets (Janković and Živković, 2014).

The latest global financial and debt crisis in Eurozone follows the explained patterns. CDS premiums as indicators of the level of default risk show high positive correlation of 94\% for sovereigns and banks as issuers.

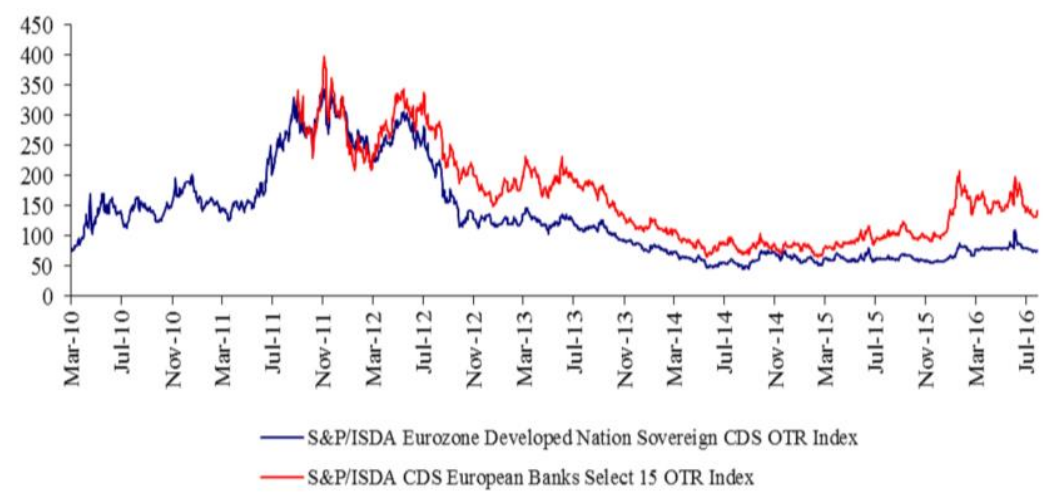

Graph 2 CDS indices for Euro zone sovereigns and European banks, in basis points Source: Authors' presentation based on data from http://us.spindices.com

The contaminated assets held in bank balance sheets led to massive insolvencies. The government interventions resulted in deficit and debt accumulation. The hidden debts in euro area periphery have been revealed. Commercial banks held significant amounts of government securities on their balance sheets, as the safest assets. Financial and debt crisis and government defaults resulted in securities rating downgrade, significant risk premium and yield increase followed by sharp drop in securities' prices. Once secure and liquid assets held on the balance sheet suddenly became less liquid and almost worthless that in parallel with private debt defaults raised liquidity and solvency issues for banks preventing them to meet capital adequacy requirements.

\footnotetext{
2 e.g. case of Fannie Mae and Freddie Mac in US and Greece in latest crises
} 


\subsection{Impact of the crisis on the financial divergence in European monetary union}

The global and sovereign debt crises in Europe revealed the shortcomings of the financial integration process. Euro zone has never reached the unification level which exists in the US since monetary union was not followed by banking and fiscal union. The Stability and Growth Pact failed in disciplining public sector and fiscal policy conduct. In addition, private sectors have accumulated significant debts that were financed through domestic banking sectors. The banks were, on the other hand,funded by European markets and financial institutions.

The substitution of national currencies in circumstances when banking regulation remains the national responsibility, means that national governments continue to carry the risk of banking crisis- the direct one (if bailing out affected banks) and indirect one (since GDP and tax revenues tend to remain low after the crisis). The national fiscal policies became the main countercyclical macroeconomic policies (Lane, 2012, p.49-50).

The private debt increased significantly in the first years of the EMU in periphery countries of the euro area. Although the public deficit in Greece had greater role in debt accumulation, in Spain, Ireland and Portugal private debt of the mostly non-financial sector had higher influence. Excessive credit growth was funded by domestic and foreign banks that led to macroeconomic imbalances and mortgage market price bubbles.

The local supervisors were in a sense permissive towards a national banking sector. The support provided was reflected in infrequent credit rating downgrades. Shift of supervision on supranational level was needed to help the reduction of the captive behavior of regulators.

The 1999-2007 was a period of good growth performances and stable financial environment that masked the accumulation of macroeconomic, financial and fiscal vulnerabilities of Eurozone periphery. The increase in private debt and current account deficits was intensive in 2003-2007. The individual fiscal policies have not been tightened, due to poor risk management, and were less countercyclical in this period. With the startup of global financial crisis, markets reacted in 2008 bringing accumulated structural weaknesses of the Eurozone members into light, triggering strong divergence process followed by market fragmentation and reversed capital flows towards the core countries. Banks faced nonperforming loans increase and liquidity squeeze.

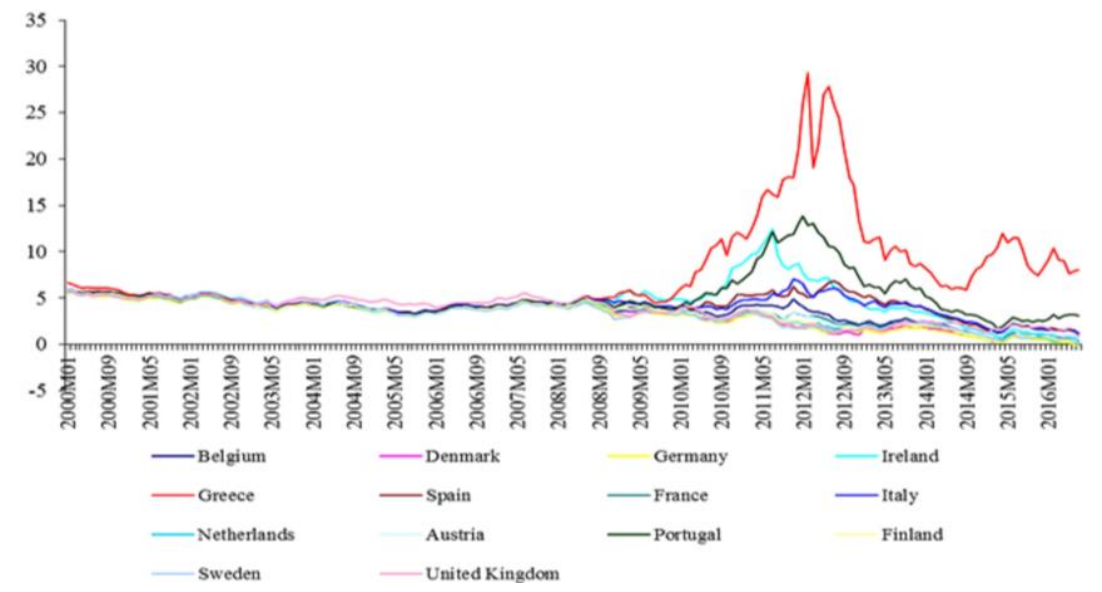

Graph 3 Divergence of sovereign bond yields (in \%) 
Source: Authors' presentation based on Eurostat data

During 2008-2009 debt markets remained calm. Demand for sovereign debt securities was even increasing since banks needed safe collateral for borrowing from ECB. The combination of domestic recessions, banking crises and withdrawal of foreign investors made basis for the sovereign debt crisis. In late 2009, countries of the euro area periphery reported higher than expected budget deficit/GDP ratios followed by rising bank losses and consequent fiscal risks that had negative impact on sovereign bond prices and yields. Markets reacted to rising credit risk and increased the yields to maturity on government debt securities while lowering their rating and prices.

The negative repercussions occurred due to the high share of now less valuable sovereign debt securities in the banks' balance sheets. In the member states with already weak sovereign the national banks were taking on a higher portion of public debt from 2009. It was particularly evident in the periphery where foreign investors were selling risky bonds and domestic banks were buying them. This process indicates an increasing fragmentation of the sovereign bond markets. Core countries, like Germany, have, on the contrary, experienced increase in sovereign bond holdings by non-residents due to the "flight to safety and quality" (Merler \& Pisani-Ferry, 2012). Despite the increased loading with sovereign debt instruments, they remained a less significant share of banks' total asset. It is important to notice that before 2007, public debt in euro area countries was mostly financed by foreign investors and not domestic financial sector. This relaxes the idea that public sector was the dominant driver of the macro imbalances. With an exception of Greece the imbalances were mostly created on the side of the private sector expenditures that were financed by the financial sector (Constâncio, 2012). The monetary transmission channel was significantly jeopardized and the ECB was forced to take on dual role of both monetary area regulator and sovereign debt market stabilizer.

In addition, the behavior of reference money market rates indicated the reduced money market's volumes, in particular, to periphery countries. Rates decrease over time but show significant volatility after the beginning of the crisis related to increasing sovereign debt risk.

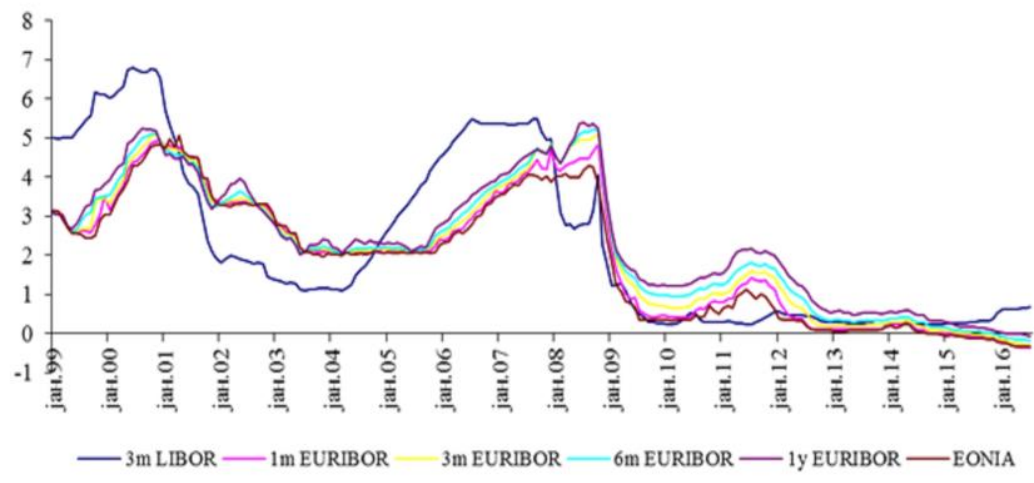

Graph 4 Reference money market rates (in \%), Jan 1999-July 2016 Source: Authors' presentation based on ECB data 
Both lending and deposit bank interest rates began to diverge across markets while the core countries started to withdraw liquidity from stressed countries back to headquarters. Foreign bank subsidiaries lost in share of the total banking sector assets.

As a consequence, the ECB monetary policy transmission process and its effect on interest rates' unification among member states became less effective. Thus, for the effective conduct of the monetary policy it is essential to reduce the financial fragmentation and to restore the monetary transmission mechanism. That is possible only when the ECB gets a chance to refocus on its primary goals while the proper crisis resolution mechanism is introduced in parallel. The joint EU/IMF programs were organized to provide a three year funding to vulnerable countries that have to implement fiscal austerity measures and structural reforms. The European Financial Stability Facility (EFSF) and European Stability Mechanism (ESM) were formed to provide resources to affected members by issuing bonds on the basis of guarantees from all member states. In order to be able to affect the risk premiums related to a fear of euro area break-up ECB had to impose strict conditionality to adequate EFSF or ESM programs. The proposed scheme of Outright Monetary Transactions (OMT) is based on this rationale. On conditionality based bond market interventions were aimed at reduction of the euro area survival risk and to help debt crisis resolution. However the three year period was too short for significant structural adjustments.

Financial and debt crisis showed some systemic weaknesses in the design of EMU bank regulation and resolution framework. They largely caused interdependence between the banking and sovereign crisis, which led to higher intensity of crisis in relation to other economies. That also made European monetary union more vulnerable to vicious circle of market expectations and deepening the crisis. When the crisis emerged, there was no supranational banking resolution framework. ECB did not have the role of the lender of last resort, and national governments where responsible for rescuing their national banking system. Having in mind the size of bank balance sheet, that meant very high costs for national budgets, and led to investor doubts about capability of some governments to pay off their debts. That led to new bank losses, since the national banks have large amounts of their national debt.

To increase the viability of EMU banking sector and break a loop between banks and sovereigns, euro area countries need credible source of unconditional liquidity - lender of last resort that is able to provide missing amount of liquidity whenever it is needed. Besides, avoiding future market distortion requires both national and supra-national regulation changes. Banking union moves the supervision of national and internationally important banks and the responsibility for rescuing them from national to European level. That should foster further financial convergence and financial integration, by unifying credit and deposit markets across Europe.

\section{THE PILLARS OF THE BANKING UNION}

According to ECB (European central bank, 2016c) the intent of banking union is to have a more transparent, safer and unified banking sector and bank supervision in Europe. Common rules and standards of bank supervision, recovery and bank resolution should be consistently applied. All banks should be treated as domestic, in the sense that all bank activities, national and cross-border, are treated the same. The financial soundness of banks 
should be independent from the country in which they are located. Timely intervention should prevent the bank failures, but in the case when it is inevitable, bank resolution should be efficient and separated from the domestic government.

Banking union has two pillars: a single supervisory mechanism (SSM) and a single Resolution Mechanism (SRM). A European deposit insurance scheme (EDIS) should be the third pillar, but it would be in full operational as of 2024 .

The goal of the single supervisory mechanism (SSM) that started on $4^{\text {th }}$ November 2013, is the foundation of single supervisory authority in Europe that is independent from national political factors. It should decrease the moral hazard problem, by respecting the principle that not all the banks would be rescued, which means that principle "too big to fail" will not work anymore. Before the crisis, European central bank had auxiliary role in the process of supervision. By establishing SSM, ECB got responsibility for supervising all banks in Europe. It directly supervises all significant banks (banks with assets of more than 30 billion euro or at the least $20 \%$ of their home country GDP- around 130 banks) (Popovic, 2016, p.12). National supervisors are responsible for supervising less significant banks. They are accountable to the ECB, which can decide to directly supervise any of these banks, if needed.

Banks in euro zone have to follow the rules of Basel III, and increase the level and the structure of their capital. The implementation of these rules will be monitored by SSM. If in the process of day-to-day supervision, the deterioration of bank balance sheet is identified, ECB should react quickly to prevent the escalation of the problem. In the case when the bank failure is inevitable, bankruptcy procedures will be shorter. Part of the single supervisory scheme is the Comprehensive assessment procedure (CA) that will be carried out on the regular basis for all significant banks, but also when needed in the case of exceptional circumstances. It should ensure that banks have adequate level and structure of capital so that they can resist possible financial turmoils.

Banking union needs the third pillar, in order to have the common playground for all European banks and to ultimately prevent the interconnection between bank and sovereign crisis. The missing pillar is the European deposit insurance scheme (EDIS). Its task is to preserve the deponents confidence in the banking system and thereby prevent the possibility of bank rush, by shifting the costs and risks of protecting depositors, in the case of local bank failures, to the Banking union. This will enhance the resistance to possible financial crisis and prevent its fast spreading among member countries, by reducing the vulnerability of national deposit guarantee schemes to large local shocks. EDIS will be filled by bank contributions, and will be fully operational from 2024 .

\section{THE FIRST RESULTS OF BANKING UNION}

Banking union is a big step towards financial stability and integration in Eurozone. This is a very new project, in its early stage. ECB became responsible for the supervision of systemic banks less than two years ago, SRM became fully operational since January 2016, but no bank resolution yet has been done. (Some Italian banks seem to be the first candidates, but Italy is trying to avoid bank resolution. It established the Atlas fund as shareholder of last resort to evade resolution even for the banks that have failed to increase their capital level (Merler 2016)). Still some early conclusions on the effectiveness of implemented 
changes could be drawn. The next part of the paper analyses the impact of changes in the bank regulatory and supervisory framework in the EMU (banking union), together with the measures taken by the ECB in the meantime (Outright Monetary Transactions ProgrammeOMT and the Quantitative Easing-QE-TLTROs), on the degree of financial integration in the euro zone and banks performances.

ECB established two composite indexes of financial integration: the price - and quantitybased FINTEC indicators. Price based FINTEC is constructed on the basis of ten price dispersion indicators on money, bond, equity and banking markets covering the period from the first quarter of 1995, thus representing an comprehensive overview of financial integration in the euro area. ECB also publishes sub-indexes for listed markets. Quantity based FINTEC is constructed on the basis of five quantity indicators, from the first quarter of 1999. Those are intra-euro cross-border holdings expressed as a percentage of euro area total holdings (intra-euro area cross-border plus domestic quantities) (European central bank, 2015b, p.119). There are three sub-indices: interbank markets (includes money and banking markets), bond and equity markets. FINTEC ranges between 0 in the case of full fragmentation, to 1 in the case of full integration.

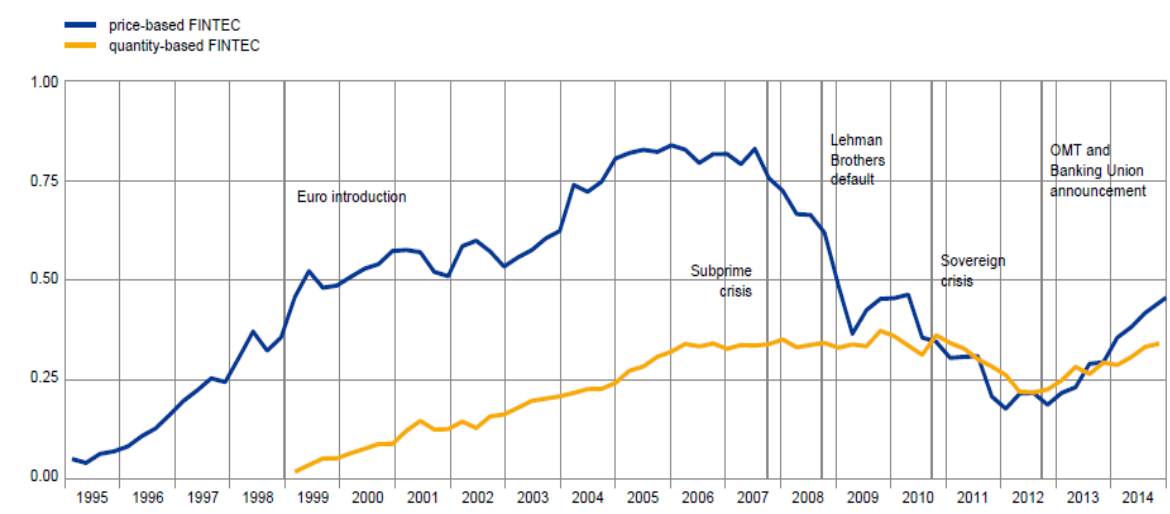

Graph 5 Price- and Quantity-based FINTECs Source: Financial Integration in Europe, April 2015, ECB, p.9

Movements of price-based FINTEC prove what was shown in the first part of the paper based on individual indicators of financial integration - that the level of financial integration in Eurozone rose until the outbreak of financial crisis in the end of 2007. Collapse of Lehman Brothers brought sharp drop in the level of indicator and sovereign debt crisis meant very high fragmentation of financial markets along national borders (In literature known as "balkanization" of the financial system) (Xafa, 2015, p.3; Smits, 2005, p.212). Situation started to improve at the end of 2012, after ECB President Mario Draghi stated that ECB would do everything that was necessary to save the euro, which was followed by the introduction of OMT program. That broke the spiral of market expectations and crisis deepening, and led to decreasing of sovereign spreads. Relatively late introduction of these measures showed structural flaws in the design of the Eurozone, due to which the functioning of the ECB as a lender of last resort was inefficient (Popovic, 2016). EU summit decision to launch banking union enabled such ECB measures by providing an adequate 
pledge for those actions that was missing before. OMT, together with the start of banking union, led to new deepening of financial integration in euro zone, although pre-crisis level is still far away. This shows how fragile reached financial integration was and that thorough, full financial integration in euro zone cannot be achieved when financial stability architecture is national based (Nouy, 2015).

Quantity-based FINTEC shows lower volatility than price-based FINTEC, but it also indicates significant influence of the debt crisis on the fragmentation of financial markets that started to decrease after OMT and banking union announcement.

The significance of OMT and Banking union announcement could be analyzed by comparing the level of financial stress before and after introducing those measures. The level of financial stress in euro area is represented in graph 6, by the Composite Indicator of Systemic Stress- CISS. CISS is a new indicator of contemporaneous stress in the financial system; it measures the current state of instability-the current level of frictions, stresses and strains in the financial system. Its focus is on the systemic dimension of financial stress. The CISS is made up of 15 mostly market-based financial stress measures divided into five categories, the financial intermediaries sector, money markets, equity markets, bond markets and foreign exchange markets (Holló et al., 2012, p.3).

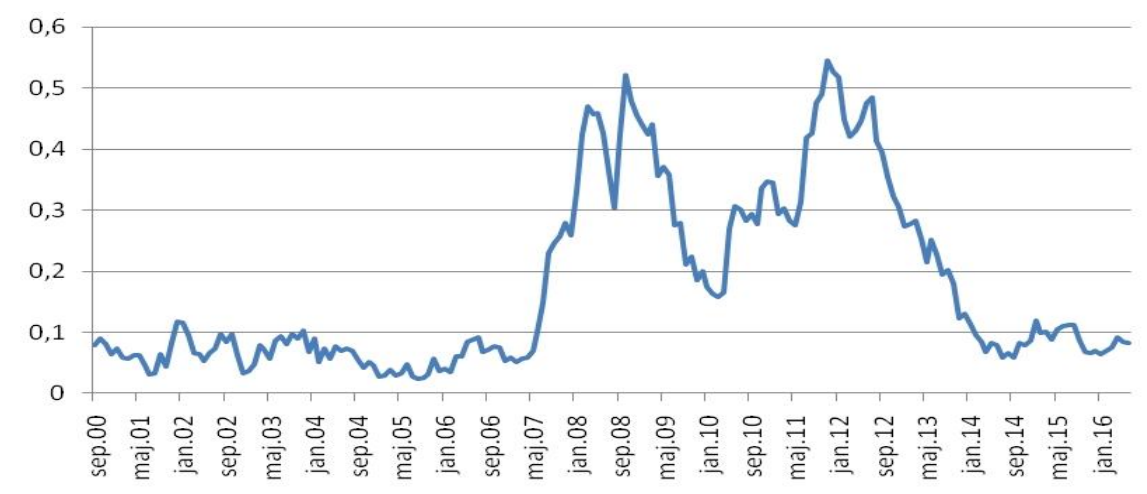

Graph 6 Composite Indicator of Systemic Stress- CISS in euro area (pure number) Source: ECB, Statistical Data Warehouse

Until subprime crisis the level of systemic stress in Eurozone was quite low, and then started to increase rapidly, reaching the peak after Lehman Brothers collapse in September 2008. During 2009 the level of financial stress started to mitigate. Enhanced credit support measures of ECB had positive results, the situation on financial markets improved, money markets spreads decreased while capital markets revived. That is why ECB announced that its non-standard monetary policy measures are no longer necessary and will be gradually discontinued. Unfortunately, immediately after tensions started to increase on some segments of financial markets- especially sovereign debt market and caused new ECB interventions. From April to August 2011, conditions in the economy started to stabilize, so ECB raised its reference rate to $1.5 \%$ in order to neutralize risks to price stability. But since August a new wave of financial and debt crisis started, and the level of financial stress reached a new peak . This forced ECB to became a lender of last resort in the full sense- to promise unconditional financial support to banks as much and 
as long as it is necessary. It introduced OMT program and banking union project. Graph 6 shows significant drop in the financial systemic risk level, after that. This was also the period of mild financial integration improvement.

The major challenge for ECB now is a very low inflation rate. It had a constant decline since November 2011 from the level of 3\%, until the January 2015, when it reached its lowest level of $-0.6 \%$. Since then situation slightly improved, but the rate of inflation still fluctuates around 0 level. Some (peripheral) member countries have quite high negative inflation rates (Cyprus $-1.9 \%$, Spain $-1.1 \%$, Latvia $-0.8 \%$ etc.), although inflation in some core members is also low or negative (Luxemburg $-0.6 \%$, Germany $0.0 \%$, Italy $-0.3 \%$, France $0.1 \%$, etc.) (Eurostat) ${ }^{3}$. There are opinions (Clays, 2014, p.15) that ECB was too late with its quantitative easing measures. It waited until June 2014 to start with massive monetary expansion in order to stimulate the economy and raise inflation expectations. This was supposed to stimulate banks to ease credit conditions and offer more credits to companies and households. The effect of measures ECB appplied since 2012 on bank lending activity is shown on the Graph 7. The amount of new bank loans to households started to decline since 2007 and loans to corporations since 2008, and there has been a significant drop in bank lending activity for years.

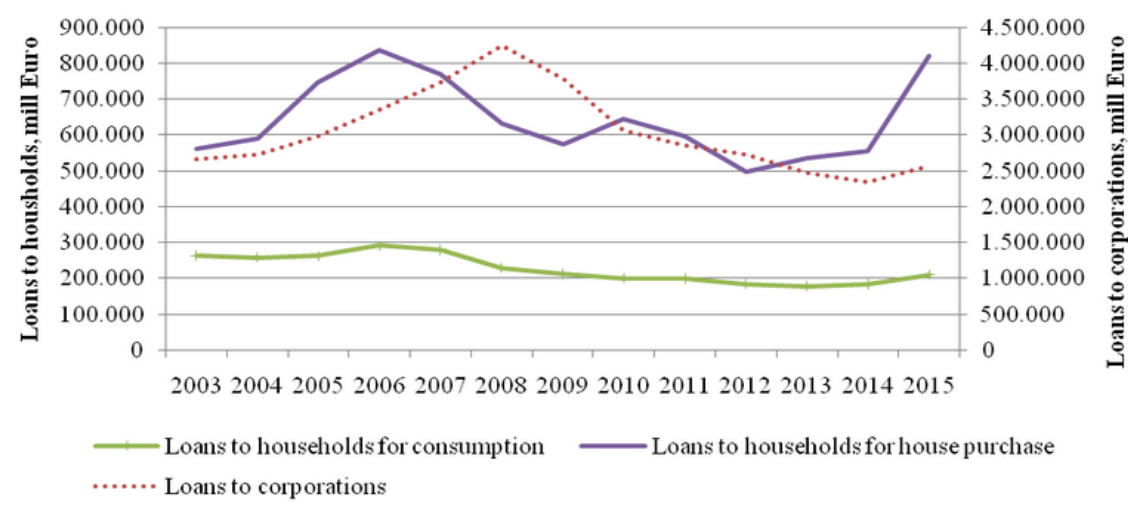

Graph 7 Bank business volumes - loans to corporations and households (new business) in the euro area

Source: Authors calculations based on ECB, Statistical Data Warehouse, 11.7.2016

Bank lending started slightly to recover in 2012, when the sum of loans to households for house purchase started to increase. The amount of new consumer loans is in mild increase since 2013, and bank lending to corporations is in increase since 2014. Banks eased terms and conditions on loans to enterprises and consumers, and ECB in its Bank lending survey expects a continued net easing of credit standards on different loans (with the exception of housing loans). Demand of enterprises for loans and credit lines is in increase since the first quarter of 2014, with the exception of the first quarter of 2015 . The main contributing factors for loan demand were inventories and working capital, the general level of interest rates, mergers and acquisitions activities and fixed investment, especially as a result of developments in Germany, Italy and Spain (European central

\footnotetext{
${ }^{3}$ Data for May 2016
} 
bank, 2016b, p.12). Demand for housing loans is in increase in all large EMU countries except in Spain. Banks had to tighten credit standards on housing loans due to the implementation of the EU mortgage credit directive, but terms and conditions are eased because of higher competition pressure. Demand growth has surpassed bank expectations, and it is expected to increase further due to the low level of interest rates, and improved housing market prospects. Net easing of credit standards for consumer loans and other credits for households was very mild, but banks expect it to continue due to competitive pressures and reduced risk perceptions. Competitive pressures, banks' cost of funds and reduced balance sheet constraints influenced significant ease of credit terms and conditions on new loans. The demand for consumer and other loans to households has an increasing trend in the majority of large EMU countries. The demand growth is mostly the result of needs to finance the durable consumer goods and to a much lesser extent the result of increased consumer confidence.

A sizeable challenge for the banks in Europe is quite long period with low profitability. Graph 8 shows some improvements in the last two years, but ROE is still significant below pre-crisis level. Besides, estimated cost of capital is now around 9\% (Constâncio, 2016), and since 2008 there has been a negative gap between banks' ROE and the cost of equity, though ECB data show significant decrease in the last two years.

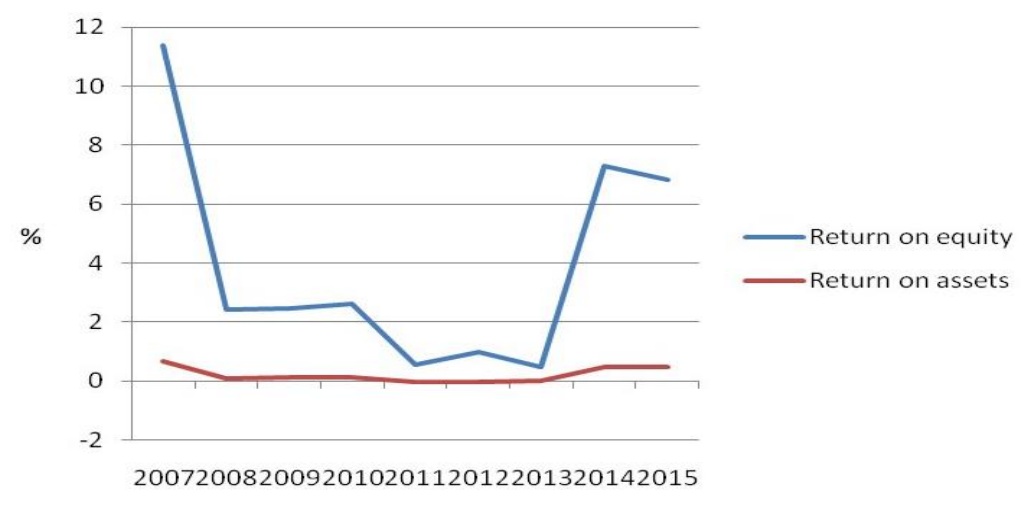

Graph 8 Bank profitability in Euro zone Source: ECB, Statistical Data Warehouse, 12.7.2016

There are also doubts if this profit recovery is sustainable. Domestic demand and GDP are in increase since March 2013, but pre-crisis level have still not been reached. Stock market developments at the global level and especially in the euro area are worrying. Euro Stoxx Banks Index shows significant fall in bank shares prices since the crisis emerged, but also during 2015 and 2016.

According to Angeloni (2016) that significantly underperforms general euro area stock index and a global index of developed countries' banks. Banks price-to-book ratios in the world are under pressure due to market skepticism regarding banks' earnings prospects, but banks in euro area are also facing low profitability issues and adjustments to new regulations and new business model. Constâncio (2016) highlighted that bank profitability reflects some cyclical and structural problems. According to him, the key 
cyclical challenge is restoring bank profit in the environment of low nominal growth, low interest rates and flat yield curve. New TLTRO II, which will be conducted from June 2016 to March 2017, are introduced to improve long-term funding conditions for banks in order to further ease private sector credit conditions and to stimulate bank lending to the real economy (European central bank 2016a). Key structural challenges for European banks are: large amount of non-performing assets, excess capacity and the incomplete adjustment of business models.

Banks in the euro area have large amounts of non-performing assets. Significant banks had, at the end of 2015 almost 950 billion euro of nonperforming loans (some $9 \%$ of EMU GDP), and their average NPL ratio is $7.1 \%$ (Constâncio, 2016). The share of nonperforming assets varies significantly across the euro area - Graph 9.

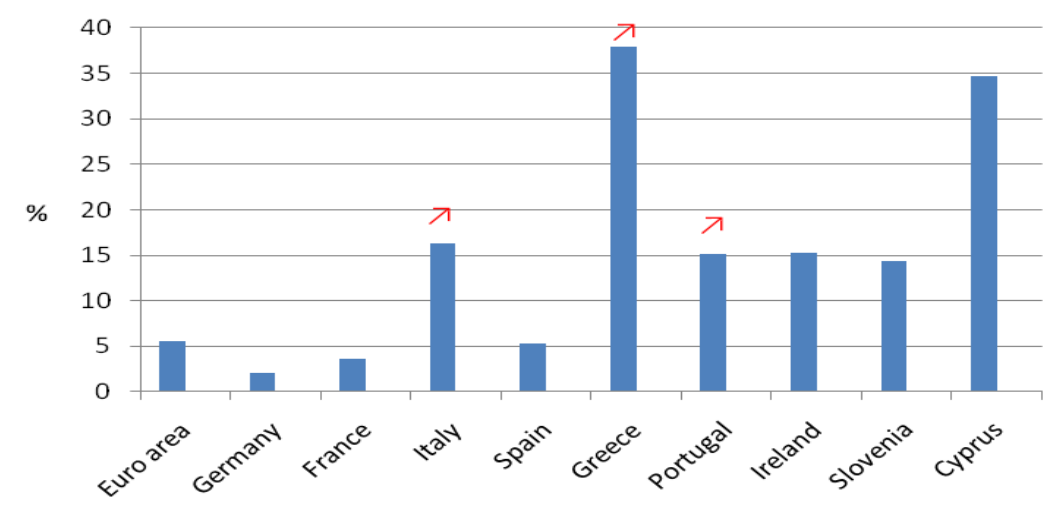

Graph 9 Gross non-performing debt instruments (\% of total gross debt instruments) Source: ECB, Statistical Data Warehouse, 12.7.2016

The worst situation is in Greece, where there is very high (38\%) and an increasing share of nonperforming debt instruments in the total amount of debt instruments (rising trend is marked with an arrow) and in Cyprus (35\%). Nonperforming debt instruments are also very high in bank balance sheets in Italy, Portugal, Ireland and Slovenia, and in the first two countries that share is increasing. High burden of banks by large amounts of nonperforming assets diminishes their profitability, while that asset is not generating revenue. Besides, those banks are high risk-averse and thus more reluctant (and less able) to lend. Single supervisory mechanism created a task force to scrutinize banks with high levels of non-performing loans and create long-term strategy for banks to reduce their NPLs levels. Positive shift is that in almost all countries and euro zone as a whole NPLs are decreasing, but negative point is low coverage ratio- only about $43 \%$ of NPLs are provisioned for (Mullin, 2016).

In some European countries, there is the overcapacity in bank sector. European banking system in general is characterized by low level of concentration. The HerfindahlHirschman Index in 2014 was lower than 750 (European central bank 2015a, p.25-26), although it had a significant increase since the crisis. There is a significant difference among countries. The lowest level of HHI is in larger economies- France, German and Italy, where banking sectors are more fragmented and include strong savings and cooperative banks. In 
smaller countries-such as in Cyprus, Estonia, Finland, Greece and Lithuania banking sectors are more concentrated (the share of assets held by the five largest banks in Greece is close to 95\%). Mergers and acquisitions, reduction of bank branches and employees per population is ongoing since the crisis emerged, and has helped to reduce banks' cost-to-income ratios, but still in some countries ratio of bank branches per capita is very high. For instance, in 2014 in Spain there were 70.2 commercial bank branches per 100,000 adults, in Luxemburg 80.4; in Italy 59.6; in Portugal 53.6; while in Finland there were 12.1, Estonia 12.4; Netherlands 14.2 and Germany 14.5 branches per 100,000 adults (The World Bank Databank). Obviously, in some countries there is a possibility for further consolidation that will diminish bank costs.

\section{CONCLUSION}

The common monetary policy without a common fiscal and other economic policies caused a significant divergence of economic performances of EMU Member States. Until the outbreak of the financial crisis, the common currency was hiding accumulated economic imbalances and financial markets have underestimated the potential risks. With the outbreak of the crisis, markets emphasized those differences, whose overvaluation jeopardized the solvency of some sovereigns and their banking sectors.

The fiscal situation in the majority of Euro area countries was healthier than in United States, Great Britain and Japan, prior to the crisis, but financial markets have become concerned about sustainability of public debts in some EMU countries. This is due to the lack of coordination of policies and externalities of common monetary policy, because of which the power of financial markets in the monetary union is much higher. Member States are in the same position as developing countries. They issue debt in the currency over which they have no control. Therefore, the inability to refinance their debts at reasonable interest rates, causes a stronger liquidity crisis to turn into a crisis of debt. Since usually the largest investors in the national bonds are domestic banks, withdrawal of investors reduces the value of their portfolio. They are faced with the problem of funding and sovereign debt crisis turns into a domestic banking crisis.

Prevention of future crisis in Monetary union involves improvement of policies coordination in the direction of taking joint actions and the elimination of externalities in monetary union. Establishing banking union is considered to be the first real European reform since the common currency. Single supervisory mechanism, independent from national political factors, should decrease the moral hazard problem, by directly supervising all significant European banks. Capital requirements are stricter, and if in a process of day-to-day supervision, ECB identifies the deterioration of bank balance sheet, it should react promptly to prevent the escalation of the problem. Single resolution mechanism is in charge for bank resolution, in the case when there are no other solutions, but with minimum use of public funds. This is especially significant in the case of nationally important banks. Investors, expecting that sovereigns will cover the losses of such banks in the event of serious financial crisis, begin to suspect the sustainability of countries' public finance. This creates the interconnection between banking and sovereign crisis. The third pillar of the Banking union, European deposit insurance scheme, aiming to shift costs from protecting bank deponents to the Banking union and thus preserving the confidence in banking system, is still missing. 
Analysis in this paper showed some positive changes in the level of financial integration and bank performances in Eurozone, after the introduction of Banking union (together by measures taken by European central bank, at the same time). Two new composite indexes of financial integration, the price-and quantity-based FINTEC indicators have an increasing trend, since 2012, indicating the rising level of financial integration. In the same period, the level of systemic stress in Eurozone has a decreasing trend. Restoring bank profitability is a serious challenge, in the situation of still quite unfavorable macroeconomic environmentzero inflation rate, low nominal growth, low interest rates and flat yield curve. New bank loans to households and corporations have a mild increase, ROA and ROE also, but markets continue to suspect banks' earnings prospects. Obviously, although all implemented and planned measures are very significant, it will take time to foster financial and economic stability in the euro area.

\section{REFERENCES}

Angeloni, I. (2016). European Banks and the Banking Union, Remarks at the European American Economic Forum. Organized by Euronext and the European American Chamber of Commerce, New York, 7 June.

Clayes, G.. (2014). The (not so) Unconventional Monetary Policy of the European Central Bank since 2008, Retrieved from: http://bruegel.org/wp-content/uploads/imported/publications/20140708ATT86588EN.pdf, Accessed on: 10 March 2016.

Constâncio, V. (2012). Towards a European Banking Union, Retrieved from: http://www.ecb.europa.eu/ press/key/date/2012/html/sp120907.en.html

Constâncio, V. (2016). Challenges for the European Banking Industry, Lecture at the Conference on: European Banking Industry: what's next?, Madrid: University of Navarra, 7 July 2016.

Diamond, D. \& Dybvig, P. H. (1983). Bank Runs, Deposit Insurance, and Liquidity. Journal of Political Economy, 91(3), pp. 401-419.

ECB, Statistical Data Warehouse, http://sdw.ecb.europa.eu/, Accessed on: 11 July 2016.

European Central Bank (2015a). ECB Report on financial structures. October 2015.

European Central Bank (2015b). Financial Integration in Europe. April 2015- Statistical Annex

European Central Bank (2016a). ECB announces new series of targeted longer-term refinancing operations (TLTRO II). ECB Press Release. 10 March 2016. Retrieved from: https://www.ecb.europa.eu/press/pr/date/ 2016/html/pr160310_1.en.html, Accessed on: 10 June 2016.

European Central Bank (2016b). The Euro Area Bank Lending Survey. April 2016.

European Central Bank, (2016c). Banking Union, Retrieved from: https://www.bankingsupervision. europa.eu/about/bankingunion/html/index.en.html, Accessed on: 1 July 2016

Eurostat. http://ec.europa.eu/eurostat/data/database. Accessed on: 11 July 2016.

Holló, D., Kremer, M. \& Lo Duca, M. (2012). CISS- A Composite Indicator of Systemic Stress in the Financial System (Working Paper Series, No 1426), March 2012.

Janković, I. \& Živković, B. (2014). An Analysis of the Effect of Currency Mismatch on a Country's Default Risk. Economic Annals, LIX, No. 201, pp. 85-121.

Lane R. P. (2012). The European Sovereign Debt Crisis. Journal of Economic Perspectives, 26(3), pp. 49-68.

Merler, S. \& Pisani-Ferry, J. (2012). Bruegel dataset of sovereign bond holdings. Retrieved from: http://www.bruegel.org/nc/blog/detail/article/874-introducing-the-bruegel-dataset-of-sovereign-bondsholdings -and-more/, Accessed on: 1 July 2016.

Merler, S. (2016). Italian Banks' Problems and the Banking Union, Confrontations Europe, Retrieved from: http://confrontations.org/la-revue-en/italian-banks-problems-and-banking-union?lang=en, Accessed on: 9 September 2016.

Mullin, K. (2016). Loan Recovery- We can See the Tunnel if not the Light. International Financing Review, 19. 1. 2016, http://www.ifre.com/loan-recovery-we-can-see-the-tunnel-if-not-the-light/21232106.fullarticle

Nouy D. (2015). The Banking Union and Financial Integration, Speech at the Joint Conference of the European Commission and European Central Bank on European Financial Integration and Stability, 27 April, Brussels. 
Popovic, S. (2016). The Function of the Lender of the Last Resort of the European Central Banks as the Response to the Financial Crisis, In: Vunjak, N., Birovljev, J. \& Sakal, M. (Eds.), Strategijski menadžment i sistemi podrške odlučivanju u strategijskom menadžmentu (pp.). Ekonomski fakultet u Subotici, Univerzitet u Novom Sadu.

Reinhart, C. M. \& Rogoff, K. S. (2008). This Time is Different: A Panoramic View of Eight Centuries of Financial Crises (NBER Working Paper 13882), ), Cambridge: The National Bureau of Economic Research.

Reinhart, C. M. \& Rogoff, K. S. (2010). From Financial Crash to Debt Crisis (NBER Working Paper 15795), Cambridge: The National Bureau of Economic Research.

Reinhart, C. M., Rogoff, K. S. \& Savastano, M. A. (2003). Debt Intolerance. Brookings Papers on Economic Activity, 1, pp. 1-74.

S\&P Dow Jones Indices, http://us.spindices.com, Accessed on: 1 July 2016.

Smits, R. (2005). The Role of the ESCB in Banking Supervision, in: Amicorum, L. \& Zamboni Garavelli, P., (Eds.), Legal Aspects of the European System of Central Banks (pp. 199-212). European Central Bank.

The World Bank Databank. www.worldbank.org. Accessed on: 11 July 2016.

Xafa, M. (2015). European Banking Union, three Years on. The Centre for International Governance InnovationCIGI, Canada.

\section{MOŽE LI BANKARSKA UNIJA POMOĆI ODRŽIVOSTI BANKRASKOG SEKTORA EVROZONE? PRELIMINARNI REZULTATI}

Iako su finansijska konvergencija i integracija zemalja članica Evropske monetarne unije dostigli visok nivo, finansijska kriza koja je prešla u bankarsku i dužničku krizu, uzrokovala je intenzivni proces podele finansijskih tržišta duž nacionalnih granica. To je značajno zakomplikovalo sprovođenje jedinstvene monetarne politike i poremetilo proces transmisije monetarne politike. Kriza u EMU je bila intenzivnija nego u drugim ekonomijama i brzo se širila među zemljama članicama. Pored toga, kriza se prenela sa banaka na države i povratno sa država na banke, kreirajući začarani krug između banaka $i$ javnih finansija.

Ovaj rad nastoji da pokaže da su adekvatna, stroga i politički nezavisna nadnacionalna supervizija banaka kao i proces rešavanja problema banaka koje su bankrotirale, neophodni za vitalnost bankarskog sektora, ali i ekonomija Evropske monetarne unije. Ona bi trebalo da povrati poverenje tržišta i ujednači pravila igre na jedinstvenom finansijskom tržištu. Iako je ovaj projekat na samom početku, postoje neki prvi ohrabrujući rezultati.

Ključne reči: bankarska kriza, dužnička kriza, bankarska unija, finansijska divergencija 